\title{
Green patents corralled
}

Driven by efforts to curb fossil-fuel use and concerns about the security of energy supplies, the number of applications for renewableenergy patents is booming.

But the patents are scattered across many databases, in different formats that are not readily searchable, leading to a lack of clarity over who owns specific energy-technology patents, and in which regions. This is not only holding up technological progress, it has also become a sticking point in international climate-treaty negotiations.

So, in a bid to better inform scientists, businesses and policy-makers, the European Patent Office (EPO) in Munich, Germany, has developed an extensive, free global database of 600,000 clean-energy patents.

The EPO trawled through 60 million patent documents and re-classified clean-energy patents according to 160 technical categories, such as carbon capture and solar photovoltaics. This should make it much easier to find patent information. The database launches in June through esp@cenet (www.espacenet. com), a gateway to European patent databases. Last year, the EPO received 1,259 renewableenergy patent applications, up 27\% from 2008, and the new database will be updated daily to include the growing number of energy patents filed at patent offices worldwide.

Users will be able to quickly find information about the dozens of components used in wind turbines, for example, and who owns the respective patent rights, says Konstantinos Karachalios, an EPO official who is overseeing the project. That should help to overcome a major hurdle in getting new energy technologies into developing countries (see Nature 462, 555; 2009). "Patents, licensing practices and technology transfer from rich to poor countries are major issues in the fight against climate change," says Ahmed Abdel Latif, the programme manager for intellectual property at the International Centre for Trade and Sustainable Development, a non-governmental advocacy group based in Geneva, Switzerland. As such, he says, this database is "vital".

Attempts to revive negotiations on an international climate-change treaty, after a disappointing result at the Copenhagen talks last year, are still being held up by the lack of information about the technologies that developing countries need to tackle global warming, says Wanna Tanunchaiwatana, head of adaptation, technology and science at the United Nations Framework Convention on Climate Change. A clean coal plant, for example, requires a bewildering array of patented processes and devices, but identifying who owns them all can be a major challenge. "Issues around [intellectual property] are not going to disappear," Tanunchaiwatana told the European Patent Forum last week in Madrid, where the new energy database was unveiled.

But whether this will help scientists working on clean technologies is an open question. "As a scientist, I'd rather rely on scientific journals than on patent descriptions," says Michael Grätzel, a chemist at the Swiss Federal Institute of Technology in Lausanne, who owns several patents on photovoltaic technologies.

There is no guarantee that data contained in patent descriptions are reliable, he warns - nor even that the experiments have been conducted as described. "A patent first and foremost signals an investor interest, but it tells you little about the actual science."

The EPO now plans to create similar databases for clean technology in the fields of transport, buildings and agriculture.

Quirin Schiermeier

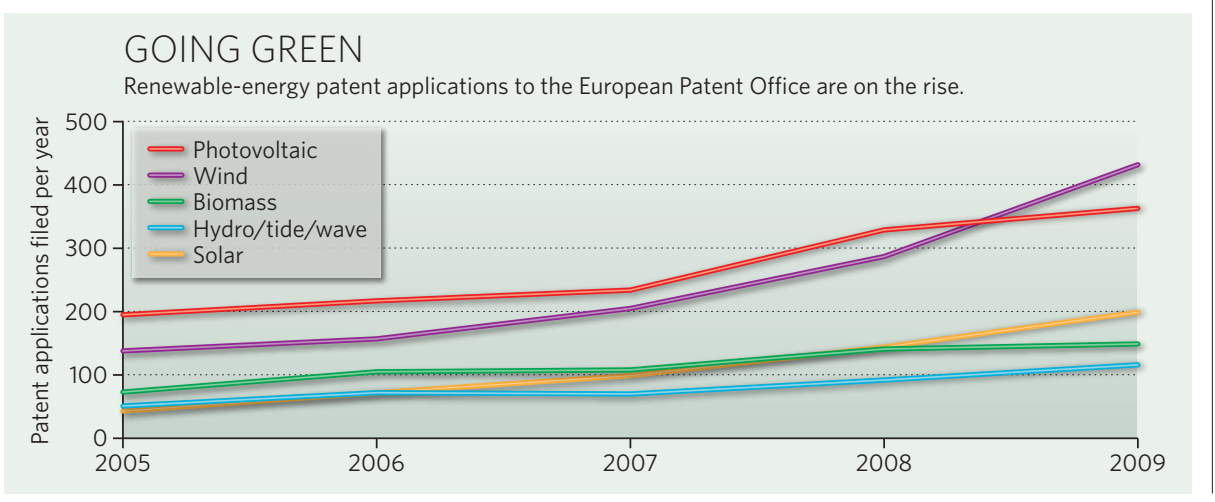

